\title{
PERLINDUNGAN HUKUM TERHADAP KONSUMEN JASA ASURANSI DI INDONESIA
}

\author{
DENY GUNTARA, SH., MH \\ deny.guntara@ubpkarawang.ac.id \\ ANWAR HIDAYAT, SH., MH \\ anwar.hidayat@ubpkarawang.ac.id \\ IRMA GARWAN, SH., MH \\ irma.garwan@ubpkarawang.ac.id
}

\begin{abstract}
Various legal instruments made to provide protection to consumers, especially consumers of insurance services, include the establishment of BMAI (the Indonesian Insurance Mediation and Arbitration Agency), OJK (Financial Services Authority), as well as those accommodated in the Consumer Protection Law which includes BPKN (National Consumer Protection Agency), LPKS (Non-Government Consumer Protection Institution, and BPSK (Consumer Dispute Settlement Agency), are layered instruments that consumers can use to fortify themselves from fraudulent acts and arbitrarily even ignore consumer rights committed by business actors. However, whether these devices are sufficient enough, in connection with the many complaints from the public against business actors, especially insurance service businesses. Many things affect the phenomenon of society, especially consumers of insurance services who feel that they are still not protected by the layers of legal instruments made, including factors from the consumers themselves, factors of business actors, law enforcement factors, and other supporting factors it should run in an ideal and harmonious manner.
\end{abstract}

\section{Keywords $\quad$ : Consumer Insurance Services, Insurance Business Actors, Consumer Protection}




\begin{abstract}
ABSTRAK
Berbagai instrumen hukum yang dibuat untuk memberikan perlindungan terhadap konsumen khususnya konsumen jasa asuransi antara lain dibentuknya BMAI (Badan Mediasi dan Arbitrase Asuransi Indonesia), OJK (Otoritas Jasa Keuangan), begitupun yang terakomodasi dalam UU Perlindungan Konsumen yang didalamnya terdapat BPKN (Badan Perlindungan Konsumen Nasional), LPKS (Lembaga Perlindungan Konsumen Swadaya Masyarakat, dan BPSK (Badan Penyelesaian Sengketa Konsumen), sudah berlapis instrumen yang dapat digunakan konsumen untuk membentengi diri dari perbuatan-perbuatan curang dan semena-mena bahkan mengabaikan hak-hak konsumen yang dilakukan oleh pelaku usaha. Namun apakah perangkat-perangkat ini sudah cukup memadai, sehubungan dengan masih banyaknya komplain dari masyarakat terhadap pelaku usaha khususnya pelaku usaha jasa asuransi. Banyak hal yang mempengaruhi terhadap fenomena masyarakat khususnya para konsumen jasa asuransi yang merasa masih belum terlindungi oleh lapisan-lapisan instrumen hukum yang dibuat, diantaranya adalah faktor dari dalam konsumen itu sendiri, faktor pelaku usaha, faktor penegak hukum, serta faktor-faktor penunjang lainnya yang semestinya berjalan secara ideal dan harmonis.
\end{abstract}

\title{
Kata Kunci : Konsumen Jasa Asuransi, Pelaku Usaha Perasuransian, Perlindungan Konsumen
}

\section{PENDAHULUAN}

Berbagai stigma buruk tentang bisnis asuransi di Indonesia belum juga lepas dari nama baik yang seharusnya menjadi modal utama bagi perusahaanperusahaan khususnya bidang jasa asuransi, seperti yang dilansir oleh beberapa situs berikut :

http://www.asuransi-jiwa.org, http://asuransikesehatan.abatasa.co.id; https://infoasuransi21.wordpress.com

tentang asuransi, sudah sejak lama melekat dalam benak kebanyakan masyarakat. Penulis juga melakukan analisa sederhana terhadap mahasiswa beberapa kelas di lingkungan Prodi Hukum Universitas Buana Perjuangan Karawang, juga beberapa kelompok masyarakat disekitar kediaman Penulis melalui wawancara secara terklasifikasi 
dimulai dari klasifikasi berdasarkan jenjang usia, mata pencahariaan, sampai pada masyarakat dalam berbagai jenjang pendidikan, untuk mengetahui secara sederhana komentar masyarakat terhadap asuransi.

\section{PERMASALAHAN :}

Poin-poin tertentu yang dianggap perlu untuk dianalisis lebih dalam terkait stigma yang tetap mendominasi pikiran masyarakat pada umumnya tentang bisnis asuransi, yakni :

1. Apakah yang menjadi penyebab stigma negatif tentang bisnis asuransi;

2. Apakah instrument perlindungan hukum terhadap konsumen jasa asuransi di Indonesia sudah memadai.

\section{METODE PENELITIAN}

Metode pendekatan yang digunakan dalam penelitian ini adalah yuridis normatif yaitu metode dengan menginventarisasi, mengkaji, dan meneliti data sekunder berupa peraturan perundang-undangan, asas-asas hukum, pengertian-pengertian hukum, kasus yang berkaitan dengan masalah yang akan penulis bahas yaitu berkaitan dengan bisnis asuransi di Indonesia.
Untuk mengkaji pokok permasalahan, penelitian ini mempergunakan metode penelitian hukum normatif. Dengan meneliti bahan pustaka yang ada. Salah satunya dengan pendekatan perundangundangan. Karena yang akan diteliti adalah berbagai aturan hukum yang menjadi fokus sekaligus tema sentral suatu penelitian. Penelitian ini akan lebih menitikberatkan pada penelitian hukum normatif. Dengan menyesuaikan diri dengan ruang lingkup dan identifikasi masalah yang telah dikemukakan diatas. Pendekatan yang bersifat yuridis-normatif tersebut akan dilakukan dengan mempergunakan bahan hukum primer, bahan hukum sekunder dan bahan hukum tersier.

\section{HASIL DAN PEMBAHASAN}

Stigma negatif tentang bisnis asuransi yang lazim terdapat di Indonesia adalah berbagai anggapan masyarakat tentang bisnis asuransi, diantaranya :

1. Asuransi menipu, penjelasan diawal manis tapi pada saat terjadi resiko maka proses klaimnya susah bahkan tak sedikit ditolak dengan berbagai alasan, atau jika dibayarpun nasabah tetap rugi; 
2. Menjadi peserta asuransi apabila diwajibkan atau dipersyaratkan saja tanpa perlu mengetahui manfaatnya;

3. Sulit mendapatkan perlindungan hukum sebagai konsumen jasa asuransi.

Stigma asuransi seperti diatas banyak faktor yang melatar-belakanginya diantaranya :

1. rendahnya tingkat pengetahuan masyarakat khususnya masyarakat pengguna jasa asuransi dan rendahnya minat keingintahuan tentang pengetahuan asuransi, sehingga saat menemukan kendala tanpa melakukan upaya apapun langsung mengambil kesimpulan yang negatif terhadap asuransi;

2. rendahnya tingkat pengetahuan dan keterampilan para pemasar asuransi, sehingga tidak atau bahkan tidak mampu memberikan pengetahuan yang cukup bagi para pengguna jasa asuransi. Atau bahkan dengan sengaja tidak memberikan pengetahuan yang cukup atau memberikan keterangan yang tidak sebenarnya asalkan produknya laku terjual, hal ini tentu saja berkaitan dengan etika dan moral para pemasar, sales, atau agensi.

3. pelaku usaha khususnya bidang jasa asuransi tidak mampu menyajikan informasi yang memadai bagi para konsumennya, tidak mampu memberikan sarana atau fasilitas memadai bagi konsumennya untuk mendapatkan informasi atau mendapatkan sarana konsultasi yang cukup, semata-mata hanya cenderung melakukan bisnis penjualan sebanyak-banyaknya untuk mendapatkan keuntungan yang sebesar-besarnya. Pelaku usaha abai akan konsep penjualan yang berbasis pelayanan yang optimal bagi konsumen sehingga tumbuh kerjasama yang baik dan saling mengerti diantara keduanya baik pelaku usaha ataupun konsumen.

4. negara tidak mampu membuat instrumen-instrumen hukum yang mampu mengakomodasi kepentingan pelaku usaha sekaligus kepentingan konsumen, atau negara tidak mampu melahirkan penegak-penegak hukum yang baik yang dapat memberikan pengayoman, 
perlindungan, dan pelayanan hukum yang baik pula, sehingga dapat menyelesaikan perkaraperkara atau sengketa-sengketa khususnya sengketa konsumen secara sederhana, cepat, dengan biaya yang ringan namun tetap memiliki kualitas dengan tidak mengabaikan asas kepastian, keadilan, dan kemanfaatan.

Terlepas dari stigma dan hal-hal yang melatarbelakanginya seperti diuraikan diatas, realitanya sudah terdapat beberapa instrumen hukum yang dibuat dalam upaya memberikan perlindungan terhadap konsumen khususnya konsumen jasa asuransi, dari instrumen hukum yang sifatnya umum sampai khusus spesifik mengakomodasi kepentingan pelaku usaha dan konsumen jasa asuransi.

\section{BMAI (Badan Mediasi dan Arbitrase} Indonesia)

Sejak tanggal 12 Mei 2006 secara resmi BMAI didirikan dan mulai beroperasi pada tanggal 25 September 2006. Pendiriannya ini adalah implementasi dari Surat Keputusan Bersama empat Menteri yaitu : a) Menteri Koordinator Bidang Perekonomian No.KEP.45/M. EKON/07/2006;

b) Gubernur Bank Indonesia No.8/ 50/ KEP.GBI/ 2006;

c) Menteri Keuangan No.357/KMK. 012/2006; dan

d) Menteri Negara Badan Usaha Milik Negara No.KEP-75/ MBU/2006 Tentang Paket Kebijakan Sektor Keuangan yang ditetapkan di Jakarta tanggal 5 Juli 2006.

Juga sejalan dengan ketentuan Lampiran III Lembaga Keuangan NonBank poin 3 program 3 tentang Perlindungan Pemegang Polis, dengan Penanggung Jawab Departemen Keuangan Republik Indonesia.

Ide Pendirian BMAI datang dari beberapa Asosiasi Perusahaan Perasuransian Indonesia yang berada di bawah FAPI (Federasi Asosiasi Perasuransian Indonesia) yaitu Asosiasi Asuransi Umum Indonesia (AAUI), Asosiasi Asuransi Jiwa Indonesia (AAJI) dan Asosiasi Asuransi Jaminan Sosial Indonesia (AAJSI) dan didukung penuh oleh Biro Perasuransian, Bapepam LK, 
Departemen Keuangan Republik Indonesia.

BMAI didirikan dengan tujuan untuk memberikan pelayanan yang profesional dan transparan yang berbasis pada kepuasan dan perlindungan serta penegakkan hak-hak Tertanggung atau Pemegang Polis melalui proses Mediasi dan Ajudikasi. BMAI dibentuk dengan tujuan untuk memberikan representasi yang seimbang antara Tertanggung dan/atau Pemegang Polis dan Penanggung (Perusahaan Asuransi). Tertanggung atau Pemegang Polis yang tidak menyetujui penolakan tuntutan ganti rugi atau manfaat polisnya oleh Penanggung (Perusahaan Asuransi) dapat meminta bantuan BMAI untuk menyelesaikan sengketa antara mereka. BMAI senantiasa berupaya untuk menyelesaikan sengketa klaim asuransi secara lebih cepat, adil, murah dan informal.

Dengan terbitnya Peraturan Otoritas Jasa Keuangan (POJK) Nomor: 1/POJK.07 /2014 tentang Lembaga Alternatif Penyelesaian Sengketa (LAPS) di Sektor Jasa Keuangan, BMAI harus mengadakan beberapa penyesuaian agar ia bisa diterima sebagai LAPS yang diakui oleh OJK. Oleh karena itu, BMAI telah memperluas kegiatannya dengan fungsi penyelenggara arbitrase dan mengubah namanya dari sebelumnya Badan Mediasi Asuransi Indonesia menjadi Badan Mediasi dan Arbitrase Asuransi Indonesia.

\section{OJK (Otoritas Jasa Keuangan)}

OJK yang berpijak pada landasan Undang-Undang No. 21 Tahun 2011 tentang Otoritas Jasa Keuangan (selanjutnya penulis menyebut UU OJK), dalam pasal 1 angka 1 menyebutkan bahwa :

"Otoritas Jasa Keuangan, yang selanjutnya disingkat OJK, adalah lembaga yang independen dan bebas dari campur tangan pihak lain, yang mempunyai fungsi, tugas, dan wewenang pengaturan, pengawasan, pemeriksaan, dan penyidikan sebagaimana dimaksud dalam UndangUndang ini".

Dalam pengertian ini OJK adalah lembaga yang memiliki kewenangan bukan saja mengatur, akan tetapi juga mengawasi, bahkan melakukan penyidikan atas perkara-perkara tertentu khususnya bidang jasa keuangan yang mana asuransi termasuk di dalamnya. 
Selanjutnya secara tegas dalam Pasal 4 UU OJK disebutkan bahwa :

"OJK dibentuk dengan tujuan agar keseluruhan kegiatan di dalam sektor jasa keuangan:

a. terselenggara secara teratur, adil, transparan, dan akuntabel;

b. татри mewujudkan sistem keuangan yang tumbuh secara berkelanjutan dan stabil; dan

c. mampu melindungi kepentingan Konsumen dan masyarakat”. sekali lagi dapat kita pertegas pada poin c bahwa OJK harus mampu melindungi kepentingan Konsumen dan masyarakat.

OJK berfungsi menyelenggarakan sistem pengaturan dan pengawasan yang terintegrasi terhadap keseluruhan kegiatan di dalam sektor jasa keuangan, sebagaimana tertuang dalam Pasal 5 UU OJK, mengisyaratkan pengawasan yang terintegrasi dengan kata lain bahwa pengawasan dalam arti yang lebih tinggi tingkat keamanannya.

Sektor usaha perasuransian adalah termasuk objek yang diawasi secara terintegrasi oleh OJK, hal ini tercantum dalam Pasal 6 huruf c UU OJK :
"OJK melaksanakan tugas pengaturan dan pengawasan terhadap:

a. kegiatan jasa keuangan di sektor Perbankan;

b. kegiatan jasa keuangan di sektor Pasar Modal; dan

c. kegiatan jasa keuangan di sektor Perasuransian, Dana Pensiun, Lembaga Pembiayaan, dan Lembaga Jasa Keuangan Lainnya”.

\section{BPKN (Badan Perlindungan Konsumen Nasional)}

BPKN berdiri dan berlandaskan pada UU No. 8 Tahun 1999 tentang Perlindungan Konsumen (selanjutnya penulis menyebut UUPK), yang dalam Pasal 31 menyebutkan :

"Dalam rangka mengembangkan upaya perlindungan konsumen dibentuk Badan Perlindungan Konsumen Nasional'.

Dalam Pasal 33 UUPK, “Badan Perlindungan Konsumen Nasional mempunyai fungsi memberikan saran dan pertimbangan kepada pemerintah dalam upaya mengembangkan perlindungan konsumen di Indonesia". Hal ini menggambarkan betapa pentingnya kedudukan BPKN dalam mempengaruhi kebijakan-kebijakan 
yang dikeluarkan pemerintah khususnya berkaitan dengan perlindungan konsumen.

Lebih detail tentang tugas BPKN termuat dalam Pasal 34 UUPK, berikut :

"(1) Untuk menjalankan fungsi sebagaimana dimaksud dalam Pasal 33, Badan Perlindungan Konsumen Nasional mempunyai tugas:

a. memberikan saran dan rekomendasi kepada pemerintah dalam rangka penyusunan kebijaksanaan di bidang perlindungan konsumen;

b. melakukan penelitian dan pengkajian terhadap peraturan perundang-undangan yang berlaku di bidang perlindungan konsumen;

c. melakukan penelitian terhadap barang dan/atau jasa yang menyangkut keselamatan konsumen;

d. mendorong berkembangnya lembaga perlindungan konsumen swadaya masyarakat;

e. menyebarluaskan informasi melalui media mengenai perlindungan konsumen dan memasyarakatkan sikap keberpihakan kepada konsumen;

f. menerima pengaduan tentang perlindungan konsumen dari masyarakat, lembaga perlindungan konsumen swadaya masyarakat, atau pelaku usaha;

g. melakukan survei yang menyangkut kebutuhan konsumen.

(2) Dalam melaksanakan tugas sebagaimana dimaksud pada ayat (1), Badan Perlindungan Konsumen Nasional dapat bekerja sama dengan organisasi konsumen internasional".

yang dalam ayat (1) huruf $f$ secara jelas dan tegas disebutkan bahwa BPKN juga bertugas menerima pengaduan tentang perlindungan konsumen baik dari masyarakat, lembaga swadaya masyarakat, ataupun dari pelaku usaha. Tentu saja hal ini disertai dengan upayaupaya proses penyelesaiannya.

\section{LPKS (Lembaga Perlindungan} Konsumen Swadaya Masyarakat)

Dalam mendorong partisipasi atau keikutsertaan masyarakat dalam hal 
perlindungan konsumen, instrumen hukum berupa UUPK juga mengakomodasi dan mengakui lembagalembaga perlindungan konsumen yang dibentuk oleh masyarakat secara mandiri, hal ini tertuang dalam Pasal 44 UUPK sebagai berikut :

“(1) Pemerintah mengakui lembaga perlindungan konsumen swadaya masyarakat yang memenuhi syarat.

(2) Lembaga perlindungan konsumen swadaya masyarakat memiliki kesempatan untuk berperan aktif dalam mewujudkan perlindungan konsumen.

(3) Tugas lembaga perlindungan konsumen swadaya masyarakat meliputi kegiatan:

a. menyebarkan informasi dalam rangka meningkatkan kesadaran atas hak dan kewajiban dan kehati-hatian konsumen dalam mengkonsumsi barang dan/atau jasa;

b. memberikan nasihat kepada konsumen yang memerlukannya;

c. bekerja sama dengan instansi terkait dalam upaya mewujudkan perlindungan konsumen;

\section{d. membantu konsumen dalam memperjuangkan haknya,}

termasuk menerima keluhan atau pengaduan konsumen;

e. melakukan pengawasan bersama pemerintah dan masyarakat terhadap pelaksanaan perlindungan konsumen.

(4) Ketentuan lebih lanjut mengenai tugas lembaga perlindungan konsumen swadaya masyarakat sebagaimana dimaksud pada ayat (3) diatur dalam Peraturan Pemerintah."

\section{BPSK (Badan Penyelesaian Sengketa} Konsumen)

Dalam rangka upaya mengakomodasi kebutuhan masyarakat baik pelaku usaha ataupun konsumen, terdapat juga BPSK yang dibentuk disetiap kabupaten dan kota guna dapat menjangkau masyarakat lebih dekat yang diharapkan juga mampu menyelesaikan sengketa-sengketa konsumen secara lebih sederhana, cepat, dan efisien. Hal ini tertuang dalam Pasal 49 ayat (1) UUPK berikut :

"Pemerintah membentuk badan penyelesaian sengketa konsumen di Daerah Tingkat II untuk penyelesaian sengketa konsumen di luar pengadilan." 
Adapun tugas-tugas BPSK selanjutnya tertuang dalam Pasal 52 UUPK sebagai berikut :

"Tugas dan wewenang badan penyelesaian sengketa konsumen meliputi:

a. melaksanakan penanganan dan penyelesaian sengketa konsumen, dengan cara melalui mediasi atau arbitrase atau konsiliasi;

b. memberikan konsultasi perlindungan konsumen;

c. melakukan pengawasan terhadap pencantuman klausula baku;

d. melaporkan kepada penyidik umum apabila terjadi pelanggaran ketentuan dalam Undang-undang ini;

e. menerima pengaduan baik tertulis maupun tidak tertulis, dari konsumen tentang terjadinya pelanggaran terhadap perlindungan konsumen;

f. melakukan penelitian dan pemeriksaan sengketa perlindungan konsumen;

g. memanggil pelaku usaha yang diduga telah melakukan pelanggaran terhadap perlindungan konsumen; h. memanggil dan menghadirkan saksi, saksi ahli dan/atau setiap orang yang dianggap mengetahui pelanggaran terhadap Undangundang ini;

i. meminta bantuan penyidik untuk menghadirkan pelaku usaha, saksi, saksi ahli, atau setiap orang sebagaimana dimaksud pada huruf $g$ dan huruf $h$, yang tidak bersedia memenuhi panggilan badan penyelesaian sengketa konsumen;

j. mendapatkan, meneliti dan/atau menilai surat, dokumen, atau alat bukti lain guna penyelidikan dan/atau pemeriksaan;

k. memutuskan dan menetapkan ada atau tidak adanya kerugian di pihak konsumen;

l. memberitahukan putusan kepada pelaku usaha yang melakukan pelanggaran terhadap perlindungan konsumen;

m. menjatuhkan sanksi administratif kepada pelaku usaha yang melanggar ketentuan Undangundang ini'.

\section{KESIMPULAN}

Instrumen-instrumen hukum yang telah ada sekarang ini dalam rangka 
memberikan perlindungan terhadap konsumen khususnya konsumen jasa asuransi sudah cukup banyak dan berlapis.

Yang menjadi catatan untuk keperluan perbaikan yang urgent adalah upayaupaya nyata dari institusi-institusi yang diberikan tugas oleh undang-undang untuk melakukan sosialisasi dan edukasi kepada masyarakat khususnya pengetahuan tentang perasuransian serta hak dan kewajibannya selaku konsumen dan calon konsumen, begitupun para pelaku usaha bidang jasa asuransi juga mempunyai tangungjawab yang tinggi untuk memberikan pengetahuan dan edukasi tentang perasuransian, kejujuran dan transparansi informasi kepada konsumen dan calon konsumennya, serta mampu mencetak atau bekerjasama dengan tenaga-tenaga pemasar yang berkualitas baik secara keterampilan maupun moralitas.

Disamping itu masyarakat selaku konsumen dan calon konsumen jasa asuransi harus senantiasa waspada dan memiliki sifat pembelajar yang selalu mempunyai kemauan untuk terus belajar serta menambah wawasannya. Dengan demikian terjalin keseimbangan yang ideal dan harmonis diantara pelaku usaha asuransi dan konsumen jasa asuransi, serta negara dalam hal ini pemerintah yang mampu menciptakan instrumen hukum yang cukup memadai didukung oleh aparat penegak hukum yang memegang teguh ethos kerja dan moralitas yang tinggi.

\section{DAFTAR PUSTAKA}

\section{Buku :}

Fuady, Munir. (2005). Pengantar Hukum Bisnis: Menata Bisnis Modern Di Era Global. Bandung : Citra Aditya Bhakti.

Hadjan, M Pjillipus. (1993). Perlindungan Hukum Bagi Rakyat Indonesia. Surabaya : PT. Bina Ilmu.

Hermansyah Abdul Saliman \& Jalis Ahmad. (2005). Hukum Dalam

Bisnis. Jakarta.

Junita Eko Setiawati. (2003).

Perlindungan Hukum Peserta Bagi

Hasil Di Suatu Perusahaan.

Bandung.

Kansil, C.S.T. (2002). Pokok-Pokok

Pengetahuan Hukum Dagang Indonesia. Jakarta : Bina Aksara. 
Muhammad, Abdulkadir \& Rilda Murniati. (2000). Lembaga Keuangan Dan Pembiayaan. Bandung : Citra Aditya Bhakti.

Prakoso, Djoko \& Murtika Ketut I. (1989). Hukum Asuransi Indonesia. Jakarta : Bina Aksara.

Raharjo, Satjipto. (1993). Ilmu Hukum. Bandung : Remaja Rosdakarya.123

Saliman Abdul Hermansyah \& Jalis Ahmad. (2005). Hukum Dalam Bisnis. Jakarta.

Sastrawidjaja, Suparman Man \& Endang. (1997). Hukum Asuransi:

Perlindungan Tertanggung Asuransi

Deposito Usaha Perasuransian. Bandung : Alumni.

Sastrawidjaja, Suparman Man. (2003). Aspek-Aspek Hukum Asuransi Dan Surat Berharga. Bandung : PT. Alumni.

Sastrawidjaja, Suparman Man. (1997). Aspek-Aspek Hukum Asuransi. Bandung : PT. Alumni.

Sedarmayanti \& Syarifudin, Hidayat. (2002). Metodologi Penelitian, Bandung : CV. Mandar Maju.
Undang-Undang Nomor 21 Tahun 2011

Tetang Otoritas Jasa Keuangan

Undang-Undang Nomor 8 Tahun 1999

Tentang Perlindungan Konsumen

Kitab Undang-Undang Hukum Perdata.

Kitab Undang-Undang Hukum Dagang.

Internet :

- http://www.asuransi-

jiwa.org/pandangan-negatif-

mengenai-asuransi-jiwa-karena-

kurang-informasi/;

- http://m.asuransikesehatan.abat asa.co.id/post/detail/31864/perl ahan-stigma-negatif-asuransipun-berkurang;

- https://infoasuransi21.wordpress .com/2014/04/30/negatiftentang-asuransi/

\section{Peraturan Perundang-undangan :}

Undang-Undang Nomor 40 Tahun 2014

Tentang Perasuransian. 